\title{
Analysis of Animal Models of Alopecia Areata(AA) Based on Clinical Features of Traditional Chinese and Western Medicine
}

\author{
Huan LI, Ming BAI,Yan-yanMIAO, Xiao-yan FANG and Ming-san \\ MIAO*
}

\author{
Henan University of Traditional Chinese Medicine, Zhengzhou, China \\ ${ }^{*}$ Corresponding author
}

Keywords: Clinical Features of Traditional Chinese and Western Medicine, Alopecia Areata, Animal Model.

\begin{abstract}
Objective: Analysis of alopecia areata animal model production methods, characteristics and characteristics of Chinese and Western alopecia areata anastomosis. Methods: To summarize the characteristics of the alopecia areata animal model, according to alopecia areata diagnosis and clinical characteristics of Chinese and Western medicine,to analyze the anastomosis of the alopecia areata model and the corresponding clinical symptoms, and to explore the advantages and disadvantages of the existing alopecia areata model and the improvement suggestions. Results: At present, there are few methods of alopecia areata, which cannot reflect the clinical symptoms of alopecia areata, not only lack the disease model which can reflect the characteristics of Alopecia areata, but also lack the method of evaluating alopecia areata. Conclusion: The establishment of alopecia areata evaluation method feasible, the establishment of disease combined with alopecia areata model is the focus of future research.
\end{abstract}

\section{Introduction}

Alopecia areata is a sudden non-scarring alopecia disease, but also a chronic inflammatory skin disease, in the world incidence rate of about $0.1 \%$ to $0.2 \%$ [1]. Its characteristics are: round or oval hair loss spots, hair loss skin thinning, feeling normal, no symptoms, can occur at any age, but more common in young people, men and women can be disease, scalp is the most common site of disease, the incidence $5 \%$ to $10 \%$ of the cases can be developed rapidly, in a few days or months all the hair off the alopecia capitis totalis (AT), a small number of serious eyebrows, beard, armpit hair, pubic hair can fall off into the alopecia universalis (AU). Foreign reports accounted for $2 \%$ of newly diagnosed patients outpatient, domestic $1.13 \%$. Chinese medicine called the wind, ghosts lap head or ghost shaving head, is a common clinical disease. In recent years, the study found that the pathogenesis of hair follicle infection tolerance for growth, $\mathrm{T}$ cell-mediated immune response to hair follicle autoantigens. At present, the treatment of the disease varied, different efficacy [2-3]. At present, the method of establishing alopecia areata is coated with rosin and paraffin, intravenous interferon- $\gamma$, intraperitoneal injection of cyclophosphamide, coated with imiquimod cream, the main modeling method is $\mathrm{C} 3 \mathrm{H} / \mathrm{HeJ}$ mouse department smear imiquimod Cream. Alopecia areata seriously affect the quality of life of patients, but also to the patient a great psychological burden. 


\section{Alopecia Areata Etiology and Pathogenesis}

\section{Alopecia Areata Modern Medical Etiology and Pathogenesis}

Modern medicine that alopecia areata is not clear, may be related to genetic factors, mental factors [4-5], immune factors, environmental factors, and even trace elements, cerebral blood flow, microcirculation and other changes. Modern molecular biology studies have shown that alopecia areata is a result of a variety of factors, involving cytokines, growth factors, neuropeptides, neurotrophic factors and other aspects, and has been in the field of gene related research, treatment also made Great progress. But a more generally accepted view is the alopecia areata lesion capillary hemorheology abnormalities leading to the direct cause of hair loss. This is with the motherland medicine alopecia areata theory of "blood stasis", "blood deficiency" coincide, for the kidney and blood circulation legislation provides a strong evidence. The current treatment of alopecia areata, including topical therapy, systemic therapy and combination therapy, topical therapy is divided into topical drug therapy and physical therapy, mainly external drug therapy, such as: glucocorticoids, minoxidil [6] and local immune regulation Agents, etc; systemic therapy, including compound glycyrrhizin, glucocorticoid and sulfasalazine. As a result of alopecia areata treatment, the combination of drugs have more significant effect, it is worth thinking [7].

\section{Alopecia Areata Pathogenesis of Traditional Chinese Medicine}

Alopecia areata is the oil "wind" category, commonly known as "ghost lap head", "ghosts". More than by the seven emotions disorders, diet section, overwork, chronic illness, serious illness, postpartum or congenital deficiency caused by, no matter what the cause, in essence, are due to blood stasis, blood discomfort, clear obscurity, Hair off not raw, resulting in viscera deficiency, blood disorders, hair root emptiness, hair drowning caused. Chinese medicine treatment of alopecia areata, more use of Tonifying kidney, Nourishing blood, Invigorate the circulation, Cold blood of traditional Chinese medicine and acupuncture massage method, the mechanism of action may include the regulation of immune, improve microcirculation, regulating the nervous system, etc., and Western medicine on the disease Pathogenesis and treatment of the direction of understanding is consistent. Specific include: internal treatment, external treatment, internal and external treatment and acupuncture treatment, internal treatment by dialectical treatment, Blood warm wind patterns with radix rehmanniae, angelica, radix paeoniae rubra and radix paeoniae alba, etc. Liver depression and blood stasis type: huoxue soup and peach siwu decoction. Liver and kidney deficiency type shippobeards Dan. The spleen kidney both deficiency type with god should Yangzhen Dan. Deficiency of both qi and blood Bazhen soup. External treatment with the whole cantharidin, Rhizoma Drynariae in $1 \mathrm{~kg}$ white wine 7 days, take the liquid to apply the affected area 4-6 times / day, 14 days for a course of treatment. Acupuncture treatment, including acupuncture treatment, acupuncture and acupuncture points injection [8].

\section{Alopecia Areata Clinical Features}

\section{Alopecia Areata Western Diagnostic Criteria}

\section{Western Diagnostic Criteria [9]}

(1) sudden or short hair hair loss, single or multiple hair, and even all the hair bald (bald), eyebrows, armpit hair, pubic hair, beard and hair off (general bald).

(2)hair loss area normal skin color, no obvious inflammatory response. 
(3)hair loss area without skin atrophy and scar.

(4) with a typical three clinical period, the stable period than the growth of the number of hair follicles decreased hair follicle atrophy.

(5)the edge of the loose hair was "exclamation mark (!)" Shape change.

\section{Alopecia Areata Diagnostic Criteria and Clinical Manifestations of Chinese Medicine}

Diagnostic Criteria. More common in middle age or hair in the long illness, hair yellow or gray, flaky or diffuse baldness, accompanied by Yaoxisuanruan, dizziness, tinnitus, pale tongue, less moss, pulse fine. Card is liver and kidney deficiency type [10-11].Alopecia areata syndrome classification based on traditional Chinese medicine theoryis shown in table 1 .

Table 1 Alopecia areata syndrome classification based on traditional Chinese medicine theory[12]

\begin{tabular}{|c|c|c|}
\hline $\begin{array}{c}\text { Classificatio } \\
n\end{array}$ & Symptoms & Tongue and Pulse \\
\hline $\begin{array}{l}\text { Blood warm } \\
\text { wind } \\
\text { syndrome }\end{array}$ & $\begin{array}{l}\text { Sudden hair loss into pieces, occasional scalp spasm or ants } \\
\text { feel, or accompanied by head heat, upset irritability, } \\
\text { irritability, hand-foot peristalsis, body weight loss, Shenpi } \\
\text { tired, teeth dry cleft lip. }\end{array}$ & $\begin{array}{l}\text { Red tongue, little } \\
\text { moss, thin pulse. }\end{array}$ \\
\hline $\begin{array}{l}\text { Liver } \\
\text { depression } \\
\text { and blood } \\
\text { stasis } \\
\text { syndrome }\end{array}$ & $\begin{array}{l}\text { Hair loss before the headache, scalp tingling or chest pain and } \\
\text { other symptoms, followed by patchy hair loss, long hair is full } \\
\text { bald. Often accompanied by a nightmare, irritability, or chest } \\
\text { tightness, chest pain, insomnia. }\end{array}$ & $\begin{array}{l}\text { Dark purple } \\
\text { tongue or } \\
\text { ecchymosis, less } \\
\text { moss, pulse string } \\
\text { astringent. }\end{array}$ \\
\hline $\begin{array}{l}\text { Liver and } \\
\text { kidney } \\
\text { deficiency } \\
\text { syndrome }\end{array}$ & $\begin{array}{l}\text { Long course of illness, usually hair yellow or gray, sick hair } \\
\text { was off, or even the body hair off, or a family history of hair } \\
\text { loss. Often accompanied by soreness and weakness of waist } \\
\text { and knees, dizziness, tinnitus, giddy dazzled, nocturnal } \\
\text { emission, insomnia, aversion to cold, less menstrual flow. }\end{array}$ & $\begin{array}{l}\text { Weak or peeling } \\
\text { tongue moss, } \\
\text { pulse or heavy } \\
\text { fine }\end{array}$ \\
\hline $\begin{array}{l}\text { qi-blood } \\
\text { deficiency } \\
\text { syndrome }\end{array}$ & $\begin{array}{l}\text { After the disease, postpartum or long illness hair loss, hair } \\
\text { loss is often increased gradually, ranging from small and } \\
\text { large, the number from small and more scalp bright and soft, } \\
\text { in the hair loss area can be seen scattered scattered uneven } \\
\text { hair, but light Light touch will fall off, with pale or pale } \\
\text { yellow, palpitations, Shenpi fatigue, shortness of breath lazy } \\
\text { words, dizziness, drowsiness or insomnia. }\end{array}$ & $\begin{array}{l}\text { Red tongue, thin } \\
\text { white fur, thin } \\
\text { pulse weak. }\end{array}$ \\
\hline $\begin{array}{l}\text { spleen-kidne } \\
\text { y deficiency } \\
\text { syndrome }\end{array}$ & $\begin{array}{l}\text { Hair loss course for a long time, usually often back lumbar } \\
\text { pain, fatigue, fatigue, edema, less satisfied, abdominal } \\
\text { swelling, stool pond, frequent urination or nocturia. }\end{array}$ & $\begin{array}{l}\text { Red tongue, teeth } \\
\text { marks, thin white } \\
\text { fur, thin pulse. }\end{array}$ \\
\hline
\end{tabular}




\section{Research Status of Alopecia Areata}

Table 2 alopecia areata modeling method and the degree of anastomosis of clinical features of Chinese and Western medicine

\begin{tabular}{|c|c|c|c|}
\hline $\begin{array}{l}\text { Animal } \\
\text { modeling }\end{array}$ & Features & Symptom and sign analysis & $\begin{array}{c}\text { The coincidence } \\
\text { degree and } \\
\text { application }\end{array}$ \\
\hline $\begin{array}{l}\text { Preparation } \\
\text { of C3H / } \\
\text { HeJ mouse } \\
\text { alopecia } \\
\text { areata } \\
\text { model } \\
\text { induced by } \\
\text { imiquimod } \\
\text { cream }\end{array}$ & $\begin{array}{l}\text { Alopecia areata animal } \\
\text { model. } \\
\text { Advantages: The animal } \\
\text { model and human alopecia } \\
\text { areata has great similarity. } \\
\text { Simple operation, high } \\
\text { success rate, good } \\
\text { repeatability, easy to promote } \\
\text { large-scale features. } \\
\text { Disadvantages: the mouse is } \\
\text { very expensive, there are not } \\
\text { the characteristics of alopecia } \\
\text { areata, epidermal granule } \\
\text { layer and spinous cell } \\
\text { hyperplasia, with } \\
\text { keratinization, dermal } \\
\text { fibroblast cells increased, } \\
\text { collagen fiber synthesis and } \\
\text { so on. }\end{array}$ & $\begin{array}{l}\text { The number of hair follicles in } \\
\text { the skin during the growth } \\
\text { period was significantly } \\
\text { reduced. The number of hair } \\
\text { follicles increased, the } \\
\text { follicular atrophy, the hair } \\
\text { follicles, the hairy hairs and } \\
\text { the hairy nipples were } \\
\text { reduced, the hairy nipples } \\
\text { moved, the hair cells and the } \\
\text { surrounding blood vessels } \\
\text { were visible with lymphocyte } \\
\text { infiltration.CD4 }{ }^{+} \mathrm{T} \text { and } \mathrm{CD} 8^{+} \mathrm{T} \\
\text { infiltration increased, IFN- } \gamma \\
\text { expression increased, the edge } \\
\text { of the loose hair was "!" Like. }\end{array}$ & $\begin{array}{c}\text { Compliance } \\
\text { with Western } \\
\text { diagnostic } \\
\text { criteria (1) (2) } \\
\text { (3) (4) (5); } \\
\text { anastomosis } \geq \\
90 \% ; \text { High } \\
\text { degree of } \\
\text { coincidence, } \\
\text { more } \\
\text { applications. }\end{array}$ \\
\hline $\begin{array}{l}\text { Preparation } \\
\text { of C57BL / } \\
6 \text { mouse } \\
\text { alopecia } \\
\text { areata } \\
\text { model } \\
\text { induced by } \\
\text { cyclophosp } \\
\text { hamide }\end{array}$ & $\begin{array}{c}\text { Alopecia areata animal } \\
\text { model. } \\
\text { Advantages: simple } \\
\text { operation, high success rate, } \\
\text { good repeatability, easy to } \\
\text { promote the characteristics of } \\
\text { large-scale. } \\
\text { Disadvantages: the } \\
\text { emergence of alopecia areata } \\
\text { do not have the } \\
\text { characteristics of the skin } \\
\text { epidermis significantly } \\
\text { hyperplasia, spinous layer } \\
\text { and granular layer thickening, } \\
\text { the number of layers } \\
\text { increased. }\end{array}$ & $\begin{array}{l}\text { The number of hair follicles } \\
\text { was significantly reduced, hair } \\
\text { follicles shortened, distorted, } \\
\text { hair follicle degeneration, was } \\
\text { auxiliaries, hair follicle } \\
\text { pigment formation, hair } \\
\text { follicle tube enlargement, was } \\
\text { degenerative changes, in } \\
\text { addition, visible skin } \\
\text { epidermis hyperplasia, spinous } \\
\text { and particle layer thickening, } \\
\text { Increased number of layers. } \\
\text { Serum levels of ICAM-1 and } \\
\text { ELAM-1 increased. }\end{array}$ & $\begin{array}{c}\text { Compliance } \\
\text { with Western } \\
\text { diagnostic } \\
\text { criteria (1) (2) } \\
\text { (3) (4); } \\
\text { anastomosis } \geq \\
70 \% ; \text { High } \\
\text { degree of } \\
\text { coincidence, } \\
\text { more } \\
\text { applications. }\end{array}$ \\
\hline $\begin{array}{l}\text { Preparation } \\
\text { of C3H / } \\
\text { HeJ mouse } \\
\text { alopecia } \\
\text { areata } \\
\text { model } \\
\text { induced by } \\
\text { interferon - } \\
\gamma(\text { IFN - } \gamma)\end{array}$ & $\begin{array}{l}\text { Alopecia areata animal } \\
\text { model. } \\
\text { Advantages: very similar to } \\
\text { the performance of human } \\
\text { progressive alopecia areata. } \\
\text { Disadvantages: Rat sources } \\
\text { are very expensive, and } \\
\text { studies have found that } \\
\text { reproducibility is poor. }\end{array}$ & $\begin{array}{l}\text { Hair removal was progressive } \\
\text { development, hair loss area } \\
\text { normal skin color, no obvious } \\
\text { inflammatory response, no } \\
\text { atrophy and scar. The number } \\
\text { of hair follicles was } \\
\text { significantly reduced, hair } \\
\text { follicles atrophy. }\end{array}$ & $\begin{array}{c}\text { Compliance } \\
\text { with Western } \\
\text { diagnostic } \\
\text { criteria (1) (2) } \\
\text { (3) (4); } \\
\text { anastomosis } \geq \\
70 \% ; \text { High } \\
\text { degree of } \\
\text { coincidence, } \\
\text { unstable, less } \\
\text { application. }\end{array}$ \\
\hline
\end{tabular}

Note: the level of anastomosis that Western diagnostic criteria and clinical relevance of the relationship. High coincidence:> 70\%; moderate degree of coincidence:> 50\%, <70\%; low coincidence: $<50 \%$. Chinese medicine diagnostic criteria as a reference. 


\section{Discussion}

Isopathic alopecia cause and pathogenesis is unknown, now that genetic factors, mental factors, immune factors, environmental factors, and even trace elements, cerebral blood flow, microcirculation and other changes related to the disease mostly Chinese medicine "oil wind" category, Chinese medicine treatment of the disease focus on dialectical treatment. The existing imiquimod cream-induced mouse model can show hair removal, the number of hair follicles in the skin during the growth period was significantly reduced, the retrograde period and the period of hair follicles increased hair follicle atrophy, hair ball, hair parent and hair nipple shrink, Hair nipple on the move, hair ball and blood vessels can be seen around the infiltration of lymphocytes. $\mathrm{CD}^{+}{ }^{+} \mathrm{T}$ and $\mathrm{CD}^{+} \mathrm{T}$ infiltration increased, IFN- $\gamma$ expression increased, the edge of the loose hair was "!" Like. So far, C3H / HeJ mice and Dundee experimental bald rats (DEBR) is the best natural animal model, suitable for alopecia areata genetics, pathogenesis and pre-clinical treatment and other aspects of research. The natural occurrence of alopecia areata has been confirmed in several mouse strains, such as: A / J and $\mathrm{C} 3 \mathrm{H} / \mathrm{HeJ}$ have a higher incidence of disease, $\mathrm{C} 3 \mathrm{H} / \mathrm{HeJ}$ mice is the most common, most characteristic, and the most practical mouse model. There are several other methods of alopecia areata, which have not been adopted by researchers because of various reasons, such as intravenous injection of IFN- [gamma] in $\mathrm{C} 3 \mathrm{H} /$ HeJ mice to induce an alopecia areata species similar to humans, but murine IFNVery expensive, and there are studies found that repeatability is poor. The alopecia areata model is the pathological model of western medicine, the alopecia areata model is not studied, and there is no alopecia areata model based on TCM syndrome differentiation. On the basis of the alopecia areata model, the method of modeling is established, and the animal model with the characteristics of TCM syndromes is established. It is more suitable for the research of Chinese medicine.

\section{Acknowledgements}

Corresponding Authors: Miao Mingsan, Male, Professor, Doctor, Mainly engaged in traditional Chinese medicine pharmacology teaching and research. Email: miaomingsan@163.com.

Fund Project: Fund Project: National "Eleventh Five-Year" support program (2008BAI53B09), Innovation Scientists and Technicians Troop Construction Projects of Henan Province (162101510003) \& (TCJ2014-391), International cooperation base (State letter (2016) 65). Author brief introduction: Li Huan, female, master graduate student, 1990-, pharmacology.

\section{References}

[1] Islam N, Leung P S, Huntley A C, The autoimmune basis of alopecia areata: A comprehensive review, J. Autoimmun Rev.14(2015) 81-89.

[2] Fu-yongLu, Hai-xiaMing, De-xianLi, Alopecia areata treatment status and progress, J. Chinese Journal of Medicine.26 (2013) 653-657.

[3] Shu-xiaYang, Advances in the pathogenesis of alopecia areata,J. Chinese Medical Abstracts (Skin Science).33 (2016) 465-470 + 7 .

[4] Radstaak M, Geurts SA, Beckers DG, Brosschot JF, Kompier MA, Work Stressors, Perseverative Cognition and Objective Sleep Quality: A Longitudinal Study 
among Dutch Helicopter Emergency Medical Service (HEMS) Pilots, J. Occup Health.2014.

[5] Payne C, Hedberg EC, Kozloski M, Dale W, McClintock MK, Using and interpreting mental health measures in the National Social Life, Health, and Aging Project, J. Gerontol B Psychol Sci Soc Sci.69 (2014)99-116.

[6] Gupta, A.K. and K.A. Foley, 5\% minoxidil: treatment for female pattern hair loss. Skin Therapy Lett. 19(2014) 5-7.

[7] Xiao Fang, YingOuYang, New progress in alopecia areata treatment, J. hong qing Medical.41 (2012) 300-302.

[8] MinZhang, Jian-da Wang,En-pinYang, Chinese medicine treatment of alopecia areata progress J. Chinese Journal of Aesthetic Medicine.19 (2010) 142-145.

[9] BianZhao, Chinese clinical dermatology, Macmillan, Nanjing: Jiangsu Science and Technology Press, 2010.

[10] Tie-tao Deng, Qun Chen, Zhen-qiu Guo, Chinese medicine diagnosis, Macmillan, Shanghai: Shanghai Science and Technology Press, 2006,8: pp.94-129.

[11]Da-can Chen, Guo-wei Ta, Clinical Medicine Diagnosis and Treatment of Dermatology and Oral Diseases, Macmillan, Beijing: People's Health Publishing House, 2004,11: p52-354.

[12] The National Standard of the People's Republic of China. Chinese Medicine Clinical Terminology Part 1 [S]. Beijing: State Bureau of Technical Supervision, GB / T16751.2-1997. 